CHAPTER 10

\title{
Srikandi Lintas Iman: Religiosity in Diversity
}

\author{
Nina Mariani Noor
}

\begin{abstract}
This article explores the religiosity of Muslim women joining Srikandi Lintas Iman, a women interfaith community in Yogyakarta. Using Glock and Stark's theory on religiosity from the sociological perspective and Tiliouine \& Belgoumidi's domains of religiosity, the research questions are how the religiosity of Muslim women in SRILI, and how their activities in interfaith dialogue contribute to their religiosity dimensions as an individual. Data was gathered through questionnaires and in-depth interviews. This paper finds out that Muslim women joining an interfaith community can improve their religiosity in several ways. Activities and programs of SRILI contribute to its member religiosity both directly and indirectly.
\end{abstract}

\section{Keywords}

religiosity - Muslim - women - interfaith dialogue

\subsection{Introduction ${ }^{1}$}

Indonesia is a plural society that consists of $25^{\circ}$ million people from several different religions and beliefs (from www.bps.go.id). Its history of independence portrays the commitments of its founding fathers to keep Indonesia as a multicultural country based on Pancasila (Five Basic Principles). Although Muslim composes the majority of Indonesian religion, almost 87 percent, Indonesia is not an Islamic state, but a Pancasila State. The people of the six religions living therein are guaranteed to practice their respective religious teachings.

1 Author Note: Nina Mariani Noor, Universitas Sunan Kalijaga. Correspondence concerning this article should be addressed to Nina Mariani Noor, Graduate School Universitas Islam Negeri Sunan Kalijaga, Jl. Marsda Adisucipto, Depok Sleman, Yogyakarta, Indonesia. Email: nina.noor@uin-suka.ac.id.

(C) KONINKLIJKE BRILL NV, LEIDEN, 2020 | DOI:10.1163/9789004416987_011 
Religious life under the New Order regime (1965-1998) was in control of harmony. The state imposed three harmonies for religious lives which consist of harmony between different religious adherents, harmony within one religious group, and harmony between religious groups and government (Sairin, 2002, p. 85). At that time, conflict within religious nuance rarely occurred. However, lately in the last decade, after the Reform Era following the fall of the Soeharto Regime in 1998, several conflicts with ethnoreligious nuances erupted in several parts of Indonesia such as Kalimantan, Poso, Sulawesi, and Ambon (Trijono, 2004).

Nowadays, Indonesians tend to be more religious than before. Jeremy Menchik argues that "the importance of religious position in the society has made Indonesia a very religious country." ("Indonesia, Negara Demokrasi yang Religius," n.d.) Indonesia is more religious than other democratic countries. Menchick states that 98.8 percent of Indonesians view that religion is important. It is higher compared to the US's 71.6 percent and India's 80.7 percent. Seventy percent of Indonesians think that a house of worship can provide an answer to the social problems. Additionally, the frequency of attending religious activities of Indonesian reaches 64.5 percent ("Indonesia, Negara Demokrasi yang Religius," n.d.).

Menchick further states that Indonesia is a "Godly Nation", an imagined community bound by common, orthodox theism and mobilized through the states in cooperation with religious organizations in society (Menchik, 2017, p. 67). It can be seen from the efforts made by some local administrations, like province and district, to apply Sharia (Islamic law) to their regions such as in Aceh Province, Ciamis District in West Java, and Bulukumba Sulawesi. Another fact showing the increase in religiosity in public spaces is the rise in the number of Muslim women wearing a headscarf, veil, or hijab, a development from a religious movement such as 212 movements when thousands of Muslims did stage rallies demanding for the imprisonment of former Jakarta Governor with the charge of blasphemy against the Qur'an.

In response to arising religion-nuanced conflicts in the last decade, some interfaith dialogue initiatives have been introduced between the state and civil society such as Provokator Damai in Ambon, Mosintuwu in Poso Sulawesi, Dian Interfidei, FPU B (Forum Persaudaraan Umat Beriman, Faith Community Forum), Forum Jogja Damai (Peace Jogja Forum), and Srikandi Lintas Iman. Most of the participants in those interfaith organizations or communities are also active in their religious organizations.

This chapter explores religiosity dimensions of Muslim women who join Srikandi Lintas Iman (SRILI), a women interfaith community in Yogyakarta which is concerned with women and children's issues. This article starts with 
the introduction of Indonesia's current context of the religious life situation, and it is followed by a study on religiosity and women. The following part is the description of SRILI in terms of its formation, programmes, and the various faiths and religions its members have. The last part is the discussion on the religiosity of SRILI Muslim women, and conclusion.

\subsection{Religiosity and Women}

Religion is a private business for its adherents; how an individual different from other individuals in terms of understanding, practice, and relating his/ her life. An individual's conviction, devotion, and veneration towards a divinity/religion are called religiosity. Religiosity, in more comprehensive meaning, involves all dimensions of religion, but it also can be used in a narrower sense in defining an extreme view and dedication to religious rituals or traditions.

Religiosity is a multi-layered concept that involves cognitive, emotional, motivational, and behavioral aspects (Hackney \& Sanders, 2003). Regarding religiosity, Gallup survey data confirms the idea that women tend to be more religious than men. "Women are more religious than men, hold their beliefs more firmly, practice their faith more consistently, and work more vigorously for the congregation" (Inc, n.d.). The Gallup survey discovers some factors supporting this fact. Firstly, "women tend to be more open about sharing personal problems." Secondly, they are more relational than men in which women can easily find their "best friend" in their congregation while men are not. Thirdly, women rely on an empirical basis for faith while men lean toward a rational basis (Inc, n.d.).

Religiosity covers several dimensions or has several spectra depending on which measurement is made. Research on religiosity has been conducted from various aspects from its measurements, dimensions, approaches, and many others. Salleh develops a theory of religiosity from the Islamic view. According to Salleh, religiosity is characterized by four dimensions: divinistic, holistic integration, transitory, and instrumentalistic. Those characteristics are embedded in its theoretical constructs and clearly apparent, such a positive outcome of the development in which the dimensions of religiosity are firmly ingrained (Salleh, 2012). A study on Muslim women and religiosity has been done by Ghulamhussein et al. in the United States. She explored the relationship between hijab and psychological wellbeing of Muslim women in the United States (Gulamhussein \& Eaton, 2015).

More research on religious dimensions was conducted by Afiatin (1998). Afiatin looked at the religious dimensions acquired by senior high school 
students in Yogyakarta and found out that the highest religious dimension was a ritual one, but it was not followed by other dimensions such as religious experience as well as religious attitude. What is more, the implementation of religious ritual was not secured by sufficient internalization of their belief and knowledge. This implementation happened since students were suggested or even forced by their parents to observe their religious ritual.

Tiliouine and Belgoumidi (2009) explored the relationships between religiosity, meaning in life, and subjective wellbeing (swB) with samples of 495 Muslim students ( 330 females, and 165 males) from Algeria. They used a Comprehensive Measure of Islamic Religiosity (CMIR) containing 60 items to measure one's religiosity. This CMIR with its domains and items entrenched in it is used to measure Islamic religiosity, which is different from the conventional items, both in their meanings and concepts since Islam has a distinctive meaning and concept of God, prophets, Sunnah, Shahadah, books, and other concepts.

\subsection{Theory and Method}

Rusu and Turliuc state that the study of religiosity usually pays attention to the differences between religious faith and religious behavior; therefore sometimes it is necessary "to build scales specific to religion under a study since the use of scales for other religious confessions may fail to capture specific issues and to provide important explanations for the study." Hence, in the process of researching religiosity, an interdisciplinary approach will give better conceptualization and explanation about religiosity (Rusu \& Turliuc, 2011, p. 360$)$.

In response to that, the discussions on this article use Glock's conceptualization of religious orientation and dimension. Glock and Stark differentiated several dimensions of religiosity-practice, belief, experience, and consequences - as indicators of norms or integration. They proposed five-dimensional models of religiosity, which are generally shared by all world religions. This Glock theory can fit with the circumstances since it is in line with my interest on religiosity of Muslim women. Those five dimensions are: 'the experiential', 'the ritualistic', 'the ideological', 'the intellectual' and 'the consequential' (Glock \& Stark, 1965).

According to Glock (Glock \& Stark, 1965), 'the experiential dimension' of religiosity refers to the achievement of direct knowledge of the ultimate reality or experience of religious emotions in the form of exaltation, fear, humility, joyfulness, and peace" (p. 40). The 'ideological dimension' shows that a 
religious person should hold certain beliefs about their religion. Belief refers to religious views such as particularism and dogmatism. The 'ritualistic dimension' includes specific religious practices expected of religious followers such as prayer, worship, and fasting. Experience stands for religious emotions and revelations. While the 'intellectual dimension' covers having some knowledge about the basic tenets of his/her faith and its religious scriptures. Lastly, the consequential dimension' reflects on the relationship with other humans and the attitudes of the adherents to other humans as a consequence of their religious belief. In other words, 'consequences' refers to the importance of religion in people's daily lives.

Moreover, since the subject of this study is Muslim women, the dimensions, especially for Muslim, are also considered in this paper. Borrowing Tiliouine and Belgoumidi (2009), there are four dimensions/domains covered. Two first interrelated dimensions were developed by Abdullah H. M. Al-Khalifah (Al-Khalifah, 1994, p. 4). Firstly, the belief (or covert) dimensions, which represents an individual's full and sincere belief in God as the Creator of the universes and as the only One worthy of worship, and one's belief in His angels, books, messengers, the Day of Judgment and the hereafter, and in fate. Secondly, the conduct (or over) dimension, which emphasizes the degree to which the belief dimensions of religiosity are reflected throughout the believer's daily behavior and actions via the full obedience and compliance to God's commands and the avoidance of those acts and behavior forbidden by God.

Tiliouine and Belgoumidi added two dimensions to those two dimensions from Al Khalifah, namely religious altruism and spiritual enrichment. Those four dimensions are used for measurement of especially Islamic Religiosity, and it was known as the Comprehensive Measure of Islamic Religiosity (CMIR). The CMIR consists of four 'domains' or dimensions. Firstly, the Religious Belief which contains 17 items dealing with faith matters, such as believing in God, judgment day, hell, paradise, sacred books, and loving the Prophet Muhammad and making him as a role model. Secondly, the Religious Practice which contains 20 items dealing with practical matters such as Islamic prayers, fasting, avoidance of alcoholic drinks, respect restrictions on clothing, hairstyle, and other prohibited actions such as watching blue film and gambling. Thirdly, the Religious Altruism which contains 12 items dealing with relational aspects, such as being kind to parents, relatives, neighbors, advising, and being tolerant toward others. Fourthly, the Religious Enrichment which contains 11 items dealing with activities that broaden religious knowledge and spiritual experiences, such as reading religious books, attending religious meetings, following religious $\mathrm{TV} /$ radio programs, and reading of and enjoying listening to the Qur'an (Tiliouine \& Belgoumidi, 2009). 
Glock and Stark and the items from CIMR with those four dimensions are used to measure the religiosity of Muslim women in SRILI. The data for this study were obtained from a brief survey and in-depth interview with some members of SRILI. The survey was carried out to only 16 persons from four religious groups: Muslim, Christian, Catholics, and local belief. The survey was conducted to get a general picture of the religious life of members. One of the SRILI members from Hinduism did not respond to the survey. The survey was done to get a general picture of SRILI's members' religiosity, while the in-depth interview was conducted to explore more explanations on the religiosity of Muslim women relating to their activities and participation in SRILI.

\subsection{Srikandi Lintas Iman: a Space to Share}

Participation and dialogue are actual practices contributing to creating public space. Therefore a culture of dialogue needs to be encouraged in which people can openly and assertively interact with others (Sinn, 2015, p. 81). SRILI is one example of creating public space for women from different religious and belief backgrounds to have dialogue and interaction. This part elaborates SRILI's formation, establishment, programs, and its activities.

Srikandi Lintas Iman was formed and declared after a workshop on "Revitalisasi Peran Perempuan dalam Mengelola Keberagaman Agama di Yogyakarta" held on 28-29 August in Wisma Mawar Asri Kaliurang. The workshop was initiated by Wiwin Siti Aminah Rohmawati who is an awardee of KAICIID International Fellows Programme in collaboration with Fatayat NU Yogyakarta. There were 32 women from different religions such as Islam, Christianity, Catholicism, Hinduism, Buddhism, and Confucianism, joining the workshop. They were from several religious women organizations like Fatayat NU (Women wing organization in Nahdhatul Ulama, the biggest Muslim organization in Indonesia), Nasyiatul Aisyiyah (Women wing organization in Muhammadiyah, the second biggest Muslim organization in Indonesia), Wanita Katholik Indonesia, and Perempuan Khonghucu Indonesia. Additionally, there were also several women from religious universities, such as Sekolah Tinggi Hindu Dharma Indonesia (Hinduism College) and Duta Wacana Christian University. There were also some from religious communities like Christianity (Gereja Kristen Jawa) and Buddhism (Vihara Vidyasena) (admin, 2015).

Generally speaking, the interreligious dialogue could spring joint action and inspire a full understanding. SRILI has been aware of it. All religions concern and are posed with challenges to the dignity of human life, such as poverty, 
violence, abuse of women and children, minority discrimination, and substantial changes in the natural environment. Different religions can address these issues together. Interreligious dialogue through SRILI should aim through the resources of religious traditions to overcome the challenges Indonesian women are facing.

Declared as women's interfaith community, SRILI has, therefore, been actively engaging in dialogue and mainly concerned with social and women- and children-related issues. Through its vision, SRILI has developed programmes on issues common to all members. SRILI is expected to make a follow up of diversity revitalization management by involving women as the primary agent of change (admin, 2015). For SRILI, strengthening sisterhood among its members is essential for developing and improving their capacities. Through joint actions those women learn to understand better, love each other, and finally live in the world together.

As an open community, SRILI has called on the women from various religious backgrounds who are concerned with women and child-related issues to join and participate in all its activities. Its membership is voluntary, and members are required to express willingness to participate in SRILI's activities actively. In 2017, its second meeting, SRILI attracted more than $5^{\circ}$ women to join. They came from 6 official religions in Indonesia (Islam, Catholicism, Christianity, Hinduism, Buddhism, Confucianism) and also from M LKI (Majelis Luhur Kepercayaan terhadap Tuhan Yang Maha Esa Indonesia), an organization of local beliefs in Indonesia.

Most of the women in SRILI are also leaders in their religious organizations. Therefore, they are supposed to have more knowledge and practices in their religions and have more power to give influence to their community. In terms of professions, most members are university students since Yogyakarta is an educational city. Those students from State Islamic University Sunan Kalijaga and Universitas Gadjah Mada were dominant. The other members are lecturers, workers, priests, homemakers, and Catholics nuns. The diversity of its members enriches and gives nuances of plurality in SRILI, and they are promising resources for SRILI future developments.

Despite mainly dealing with programs on women- and children-related issues, SRILI's initial development focused on attracting the attention of its members to get to know each other about their beliefs and faiths. Therefore, programs are introduced to its members to reflect interfaith dialogue and understand each other.

The interfaith dialogue consists of interaction between people of different faith backgrounds, with the goal of a mutually beneficial relationship and understanding. Therefore, during the first engagement in joining the group, new 
members were given time to have an introduction and eliminate prejudice with other members. Members also gained knowledge of other religions and managing pluralities. The new members were also given knowledge of how to build awareness of the importance of women in interfaith dialogue. The basic knowledge is expected to be a basis for every SRILI members to have the same vision of interfaith dialogue.

Any formal or informal relations among the SRILI members can be done through dialogue. The dialogue includes interaction with other members inside or outside SRILI activities and/or academic and non-academic level.

\subsection{Being More Religious in Inter-Religious Community}

The successful interfaith dialogue and building relationships through interconnectedness essentially depends on the maintenance of religious identity. It is critically essential for a person in the interfaith dialogue to know their belief so that the conversation taking place in the dialogue could be fruitful and successful. Diana Eck called it the "commitment to being at the table with one's commitments." True interfaith discourse happens with those adherents who are comfortable with and devoted to their religious convictions. Religion - and religious difference - is usually brought up and discussed in dialogue as the general acknowledgment to clarify that people engaging in dialogue come from very different backgrounds. However, once that difference was acknowledged, it was shunted to the side, and love and humanity as a common language was highlighted. Consequently, the discussion about differences in the theological and religious matter is discharged (Eck, 2006).

Muslim women joining SRILI come from different Muslim schools. Most numbers are from Fatayat NU, and the rest are from Nasyiatul Aisyiah, Ahmadiyah and those who do not have women's organization references. In doing their interfaith dialogue, they keep and maintain their religious identity, such as they wear a veil and observe prayers when they are having activities with SRILI. Those women have their own religious experiences. Generally, they are hereditary Muslims who were born and brought up in Muslim family and also Muslim communities since Indonesia population is majority Muslim. That is why they have a variety of religious experiences and knowledge. Most of those women have their experiential religious dimension on a process "believing by doing." It means that they believe their faith is getting stronger because of a process of learning and experiencing. They do not have a shocking special religious experience that changes their level of faith. The following is what an informant said about her religious experience: 
I do not have a dramatic religious experience that strengthen my faith to Islam. I was born Muslim and brought up in a Muslim family and a Muslim community. Islam is my only choice. I believe the doctrine and teaching given to me through school and community that Islam is a perfect religion among the divine religions. So far, my reading and study about Islam strengthen my belief.

Interview with FF, 6 September 2017

Islam obliges its adherents to observe several religious rituals such as prayer (Salat) five times a day, giving alms, doing fasting, and going on a pilgrimage to Mecca. The frequency and regularity of doing these rituals show the religiosity. Based on the quick survey, most Muslim women in SRILI observe their religious rituals such as prayer and giving alms regularly. Moreover, in every activity held by SRILI they have time to do their prayers. Some of them also have had their pilgrimage to Mecca, both umrah and hajj. In Indonesia, Muslims who are doing prayer regularly, going pilgrimage to Mecca are seen as a religious Muslim in Indonesia. Rituals that can be seen are still used for measurement of others' religiosity. The results of research on women Muslim in SRILI is in line with what Menchik (2017) found out in his research.

Interfaith dialogue is a place where Muslim women can meet, share, and learn with other women from other religions. Since there are special events in SRILI aimed to get to know each other among their members on religious and theological issues, Muslim women get opportunities to interact with other women and know more about other beliefs. There are knowledge exchanges between them where Muslim women have to answer several questions concerning their religions raised by other women in SRILI. Several common questions are, among others: why women should wear hijab, what is its theological reason for wearing hijab, why Muslims do polygamy, and why Muslims take ablution before observing prayer.

Those questions indirectly forced those women Muslims to learn about their religion and religious rituals that they observe regularly. They might never question their religious ritual and other religious obligation, about the theological reason behind those obligations. One of the Muslim women stated that since she takes part in the interfaith dialogue, she has to renew and improve her knowledge of her religions in order to explain it to others. Besides, those well-educated Muslim women in SRILI make them easily elevate their knowledge about Islam.

One of the informants stated: "there is an encounter in dialogue and knowledge exchange. When there is a question addressed to me that never been asked before as a Muslim, such as why I wear a veil, or if it is an obligation for 
women Muslim, I have never thought about its theological reason until I have those questions. Consequently, those questions force me to explore and study more about my religion" (Interview with WW, 1 September 2017).

Another religious dimension is an essential dimension in which religiosity is seen from the attitudes of adherents that reflect their religious teaching and beliefs in their everyday. In Islam, many activities can be used to measure this religiosity, for example giving alms, and treating and respecting other people. Based on the survey and interviews, I found out that the frequency of women donating for their religious activities is high. It can be seen that there are more than half of them who donate for religious activities as often as they can. They also think that in giving donations, they do not need to see the religion of the receivers.

Muslim women in SRILI think that joining SRILI and being active in its activities and programs has given them a chance to treat others as their religious teaching command them to do so. For them, SRILI is a space where they can interact with those from other religions and beliefs while they can still practice their religious teaching. Furthermore, they do not worry about the possibility of bothering their faith or of being converted to other faiths.

Looking at those Muslim women's religiosity from Tiliouine and Belgoumidi's (2009) domains, they are in favor of religious belief, religious practice, religious altruism, and spiritual enrichment. Their religiosity is getting stronger and more in line with their activities in SRILI.

\subsection{Interfaith Dialogue, Religiosity and Religious Maturity}

As mentioned earlier, most Muslim women joining SRILI said that they are not afraid of being interfered by other religious teaching or converted to other religions by participating actively in SRILIs activities. Most of them feel that their faith and belief as Muslims get stronger than before joining SRILI. Besides, they gain more understanding of other faith or religions. They continue to work together to deal with women and children's issues through SRILI.

From the analysis, it revealed that those Muslim women are religiously mature. Tsang and McCullough (2003) point out that religiosity as a relevant construct for positive psychology because some forms of religiosity correlate significantly with physical and mental health, tolerance, pro-social behavior, and positive interpersonal relationships. Muslim women in SRILI have shown their religious maturity as Malony (1985) said, as experiencing fellowship; persons with this maturity enjoy being around with people from different religions, 
ethnicities, and backgrounds. They also have a close relationship with persons both within their religious groups and different religious backgrounds.

The spiritual maturity of these Muslim women is in line with their religiosity. Those women also have religiosity from altruistic domains, i.e., tolerating others and helping people with their difficulties for God's sake. What is more, those Muslim women have the open-mindedness to learn new thing and to appreciate differences. It can be said that in terms of religiosity and religious maturity, those women have finished with themselves. SRILI, as a community for women from a different religious background, has become a space for Muslim women to improve their religiosity in several items of dimensions as well as to maintain their religious maturity.

\subsection{Conclusion}

To sum up, interfaith dialogue initiated by SRILI is an effort made to build bridges between women from different religious identities to respond to women and children's issues in Yogyakarta. Looking at the composition of SRILI members consisting of women leaders from various religious backgrounds and also their religious activities, this study showed that most of them including Muslim women in SRILI are "religious people" since they have high religiosity and are also religiously mature.

Furthermore, SRILI programs and activities, on the one hand, are building bridges, providing opportunities to its members to know each other and consequently understand each other. On the other, SRILI also creates a space for those women to grow their knowledge of their religion. In other words, SRILI contributes to improving the religiosity of its members, especially the knowledge dimension for its Muslim members.

This study is initial research only studying Muslim women. Therefore further studies to other religious groups are strongly encouraged, and would be beneficial.

\section{References}

admin. (2015, November 30). Profil Srikandi Lintas Iman Yogyakarta. Retrieved September 21, 2017, from http://srikandilintasiman.com/hello-world/.

Afiatin, T. (1998). Religiusitas remaja: Studi tentang kehidupan beragama di daerah istimewa Yogyakarta. Jurnal Psikologi, 1, 55-64. 
Al-Khalifah, A. H. M. (1994). Religiosity in Islam as a protective mechanism against criminal temptation. The American Journal of Islamic Social Sciences, n1(1), 1-12.

Eck, D. L. (2006). What is pluralism? | The Pluralism Project. Retrieved October 1, 2017, from http://pluralism.org/what-is-pluralism/.

Glock, C. Y., \& Stark, R. (1965). Religion and society in tension. Chicago: Rand McNally.

Gulamhussein, Q.-ain, \& Eaton, N. R. (2015). Hijab, religiosity, and psychological wellbeing of Muslim women in the United States. Journal of Muslim Mental Health, 9(2), $25-40$.

Hackney, C. H., \& Sanders, G. S. (2003). Religiosity and mental health: A meta-analysis of recent studies. Journal for the Scientific Study of Religion, 42, 43-55.

Inc, G. (n.d.). Why are women more religious? Retrieved September 25, 2017, from http:// news.gallup.com/poll/7432/Why-Women-More-Religious.aspx.

Indonesia, Negara Demokrasi yang Religius. (n.d.). Retrieved September 25, 2017, from http://www.republika.co.id/berita/koran/khazanah-koran/16/o3/10/o3tcw7 8 -indonesia-negara-demokrasi-yang-religius.

Malony, H. N. (1985). Assessing religious maturity. In Psychotherapy and the religiously committed patient (pp. 25-34). New York: Haworth Press.

Menchik, J. (2017). Islam and democracy in Indonesia: tolerance without liberalism. New York: Cambridge University Press.

Rusu, P.-P., \& Turliuc, M.-N. (2011). Ways of approaching religiosity in psychological research. The Journal of International Social Research, 4(18), 352-362.

Sairin, W. (Ed.). (2002). Kerukunan umat beragama pilar utama kerukunan berbangsa: butir-butir pemikiran (Cet. 1). Jakarta: в Рк Gunung Mulia.

Salleh, M. S. (2012). Religiosity in development: A theoretical construct of an Islamic-Based Development. International Journal of Humanities and Social Science, 2(Special Issue), 266-274.

Sinn, S. (2015). Public space, agency and dialogue in plural societies. In Religious Plurality and the Public Space:Joint Christian-Muslim Theological Reflections (pp. 7181). The Lutheran World Federation.

Tiliouine, H., \& Belgoumidi, A. (2009). An exploratory study of religiosity, meaning in life and subjective wellbeing in Muslim students from Algeria. Applied Research Quality Life, 4, 109-127.

Trijono, L. (Ed.). (2004). Potret retak nusantara: studi kasus konflik di Indonesia. Yogyakarta: CSPs Book.

Tsang, J., \& McCullogh, M. E. (2003). Measuring religious constructs: A hierarchical approach to construct organization and scale selection. In Handbook of Positive Psychological Assessment (pp. 345-36o). Washington, D.C.: American Psychological Association. 